\title{
PRODUCTION OF ALUMINIUM FOAM AND THE EFFECT OF CALCIUM CARBONATE AS A FOAMING AGENT
}

\author{
M. Aboraia, R. Sharkawi, M.A. Doheim \\ Mining \& Metallurgical Department, Assiut University, Faculty of \\ Engineering, Assiut, Egypt - Postal Code: 71518 \\ E-mail: eng refaie2000@yahoo.com
}

(Received February 22, 2011 Accepted April 2, 2011)

\begin{abstract}
Metallic foams are gaining ground as important new engineering materials.Aluminium foams were produced with different densities using different percentages of calcium carbonate as a foaming agent. The mechanical properties of the foamed material were tested using uniaxialcompression test. Plateau stress $\sigma p l$, densification strain $\varepsilon d$ and energy absorption capacity $U$, were calculated. The obtained results show that the collapse strength and the absorbed energy of foams increase with increasing the density.
\end{abstract}

\section{INTRODUCTION}

Metallic foams are a new, as yet imperfectly characterized, class of materials with low densities and novel physical, mechanical, thermal, electrical and acoustic properties. They offer potential for lightweight structures, for energy absorption, and for thermal management. The present most commercially available metal foams are based on aluminum or nickel. Methods exist for foaming magnesium, lead, zinc, copper, bronze, titanium, steel and even gold [1]. The properties of metallic foam and other cellular metal structures depend upon the properties of the metal, the relative density and cell topology (e.g. open or closed cell, cell size, etc.)[1]. In order to improve the cellular structure of the materials and also to make the production technologies more reliable and reproducible, foam stability of liquid metals, i.e. avoidance of rupture and drainage, has to be understood and controlled [2]. Many distinct process-routes have been developed to make metal foams [1,2]. Metallic foams can be produced by melt foaming process [3-5]. In this fabrication technique, some viscosity increasing agents such as $\mathrm{SiC}, \mathrm{SiO} 2, \mathrm{MgO}$ and $\mathrm{Al} 2 \mathrm{O} 3$ particles are added to the metallic melt in order to make the melt get an appropriate viscosity. It was suggested that the viscosity increasing agent not only stabilized the cell wall but also affected the mechanical properties of the foams [5-11]. $\mathrm{TiH} 2$ is the most popular foaming agent [1-5], but the relatively new trend in metallic foam production used the Calcium carbonate as a foaming agent [8-14]. The carbonate decomposes within the molten metal and forms $\mathrm{CaO}$ solids and the reactive gas $\mathrm{CO} 2$. Under conditions of aggressive agitation, the gas bubbles formed within the molten metal are ruptured and fragmented, exposing more of the reactive gas to the molten metal. This gas reacts with the molten aluminum forming $\mathrm{CO}$ gas and in-situ formed $\mathrm{A} 12 \mathrm{O} 3$. The $\mathrm{CO}$ and $\mathrm{CO} 2$ gas bubbles, as well as $\mathrm{A} 12 \mathrm{O} 3, \mathrm{CaO}$ and other metallic oxide phases, stabilize the liquid metal suspension by modifying the viscosity and surface energy of the molten metal $[13,14]$. In this work the Al-foam is produced using calcium carbonate $(\mathrm{CaCO} 3)$ as a foaming agent and the effect of $\mathrm{CaCO} 3$ wt.\% addition on mechanical properties of aluminium foam is studied. 


\section{EXPERIMENTAL WORK}

\subsection{Materials Used}

The following materials are used:

- Metal: commercial pure aluminum $(99.86 \% \mathrm{Al})$ supplied from the Aluminium Company of Egypt.

- Foaming agent: Calcium carbonate powder was used as a foaming agent, supplied by (El Gomhouria Co.), the purity of powder is (99\%) with size cut less than 38 $\mu \mathrm{m}$. In order to determine reasonable foaming temperature of Aluminium melt, the decomposition temperature of $\mathrm{CaCO} 3$ blowing agent has to be measured. So, $\mathrm{CaCO} 3$ blowing agent was studied with Thermogravimetric Analysis with heating rate of $20 \circ \mathrm{C} / \mathrm{min}$. the decomposition is beginning from about $650 \circ \mathrm{C}$ to about 780 ${ }^{\circ} \mathrm{C}$ as shown in Fig. 1 so that the temperature of melt in foaming process was taken about $725^{\circ} \mathrm{C}$. at higher temperature (higher than $780 \circ \mathrm{C}$ ) the calcium carbonate will decompose very quickly without good distribution in the melt.

Thermal Analysis Result

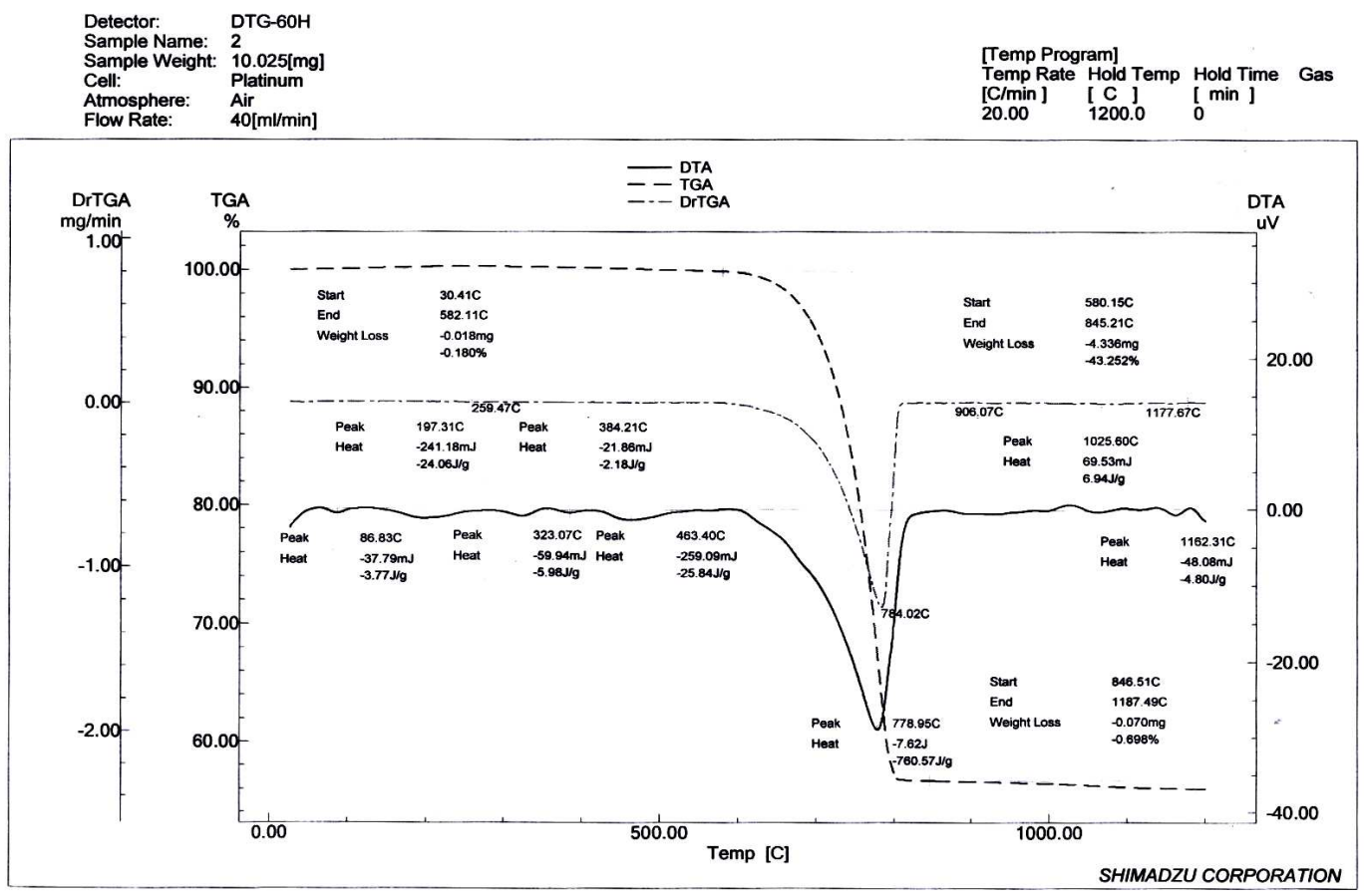

Figure 1: Thermal analysis of $\mathrm{CaCO} 3$

- Alumina: Highly pure alumina powder from the aluminum company of Egypt for increasing the viscosity of molten aluminium, and it has the following particle size distribution as shown in Table 1. 
Table 1: Particle size distribution of al $\mathrm{A}_{2} \mathrm{O}_{3}$

\begin{tabular}{|c|c|c|c|}
\hline size, $\boldsymbol{\mu m}$ & $\mathbf{w t} \%$ & size, $\boldsymbol{\mu m}$ & $\mathbf{w t} \%$ \\
\hline$-200+160$ & 0.86 & $-71+63$ & 9.32 \\
\hline$-160+125$ & 2.05 & $-63+53$ & 8.57 \\
\hline$-125+100$ & 7.03 & $-53+45$ & 8.26 \\
\hline$-100+90$ & 17.93 & $-45+38$ & 3.11 \\
\hline$-90+71$ & 40.43 & $-38+0$ & 2.44 \\
\hline
\end{tabular}

\subsection{Equipments}

Cylindrical steel mold with dimensions of $8.5 \mathrm{~cm}$ inner diameter, $22.9 \mathrm{~cm}$ height and 2 $\mathrm{mm}$ thickness was used for the melting and foaming process. Muffle furnace for melting process, and another tailored muffle furnace with $10.5 \mathrm{~cm}$ cylindrical chamber with a temperature controlling unit were used for the foaming process. For mixing a steel mixer with high speed motor was used. Optical microscope with image analysis program (MetallurgyPlus- image analysis system Nascent Technology Inc.) for microscopically inspection. The mechanical properties characterizations were done by universal testing machine (model fritz heckert EU20).

\subsection{Experimental Procedure}

A flow diagram of the foaming process is shown in Fig.2. About 500 gm of the aluminum was melted, the temperature of a cylindrical steel mould coated with antisticking material (commercial calcium carbonate) was adjusted in a resistance furnace and the molten metal poured into the mould. The temperature of molten metal was about $725{ }^{\circ} \mathrm{C}$ and $\mathrm{Al} 2 \mathrm{O} 3$ powder was added, the mix was then stirred with stainless steel mixer to keep the efficient uniform distribution of alumina particles in the molten aluminum at $1500 \mathrm{rpm}$ for about $1 \mathrm{~min}$. Then, the mixer speed is adapted at $2000 \mathrm{rpm}$ and the foaming agent $(\mathrm{CaCO} 3)$ is added and mixed for about $30 \mathrm{sec}$. All the mixing process was carried out in the furnace at $725{ }^{\circ} \mathrm{C}$. This temperature led to thermal decomposition of the foaming agent as shown in Fig.1. The mould is then taken out and let in air to cool.

\subsection{Investigations and Measurements}

\section{- Measurement of density:}

The volume of sample is calculated from its dimensions. The sample was weighed and the density was calculated by dividing sample weight over its volume.

\section{- Pore size}

A scanned image of the produced Al-foam specimen is shown in Fig.3. it will be used for pore characterization. 


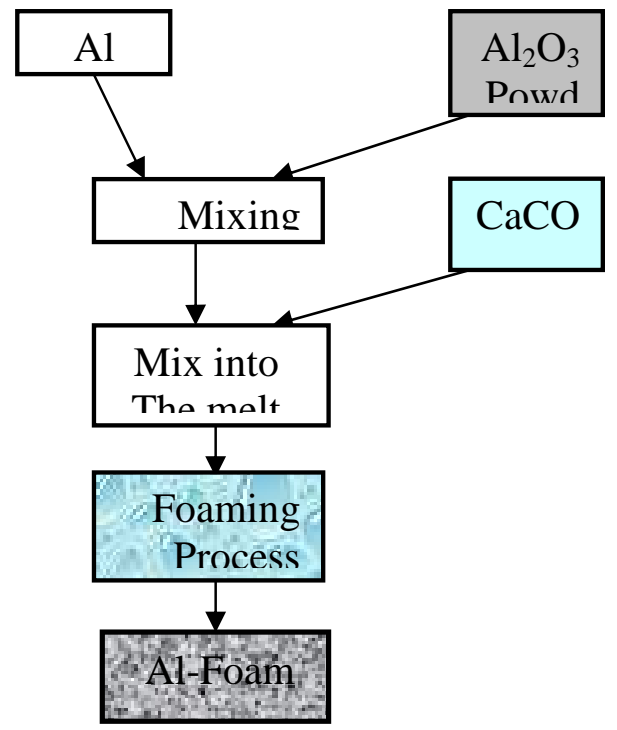

Figure 2: A flow diagram of the foaming process

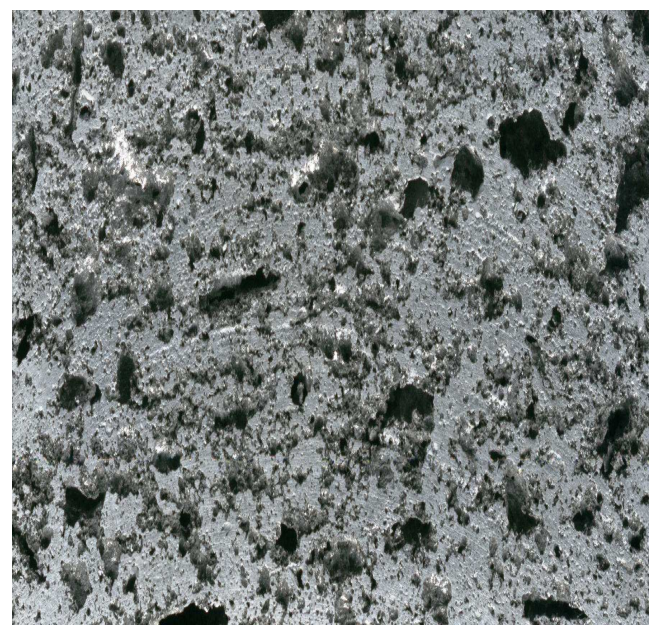

Figure 3: Scanned image showing pore distribution of the produced foam specimen

A well-conditioned, flawless surface appearance can be observed. In order to measure the porosity fraction, porosity size (maximum and minimum diameter) of the specimen, an image analysis on a cross section of the foaming direction was conducted with an image analyzer (metallurgyplus software). Since the shapes of pores were not perfect circles, equivalent diameter is used for the pore size. An equivalent diameter is the diameter of a circle having the same area as the pore, which was calculated automatically by image analyzer.

\section{- Compression test}

Due to the potential applications of metallic foams in the field of crash and energy absorption, compressive test of metallic foams has gained a great importance that 
enables to characterize their mechanical properties [15]. Twenty five compression test specimens were machined with the size of $85 \mathrm{~mm}$ diameter and $35 \mathrm{~mm}$ height, the surface skin that is inevitably generated in the process of the production of $\mathrm{Al}$ foam was retained. In the preparation of the specimen, the minimum dimension of the specimen should be at least 7 times the pore size to avoid porosity size effect [16].The compression tests were carried out on aluminum foams at a constant loading rate of 2.5 $\mathrm{KN} / \mathrm{sec}$

\section{RESULTS AND DISCUSSION}

\subsection{Microstructural Characterization}

All foam samples show heterogeneities and imperfections in their structure. A representative SEM image of the foam is shown in Fig.4. In addition to heterogeneities, morphological defects such as fractured or collapsed cell walls, irregular cell shape and cell wall buckling are prominent in the cell structures. Pores with fractured cell walls form large, non-equiaxed cells with their neighbors. Moreover, these elongated cells often contain buckle in the cell walls thus providing less mechanical support upon loading. This behavior was observed by others [17].

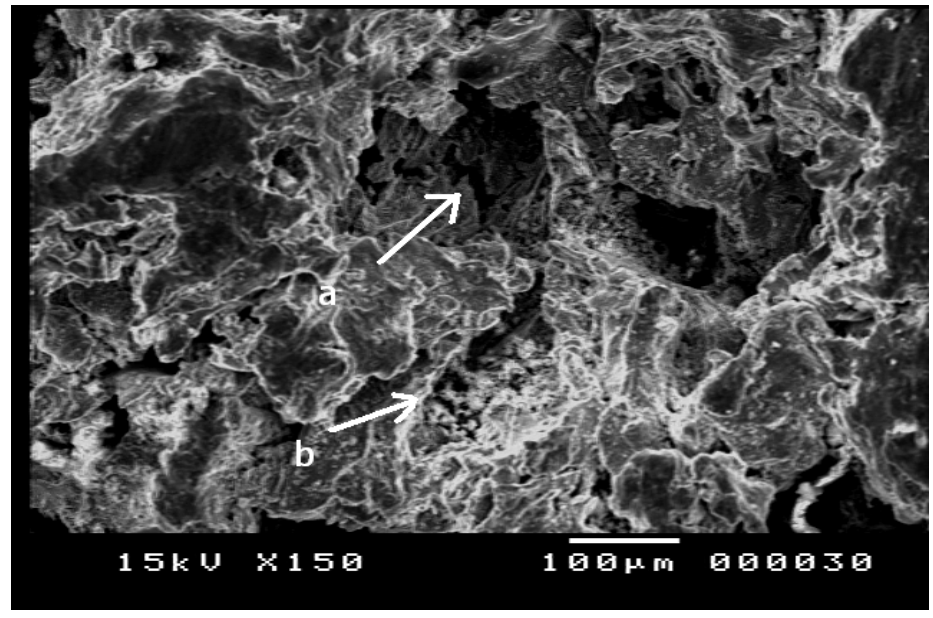

Figure 4: SEM image of Al-foam produced using $\mathrm{CaCO} 3$ as a foaming agent (afracture and b- irregular cell shape)

Pore size was determined for the specimens using optical microscopy and image analysis and the results are as shown in Table2.

Table 2: Pore size of Al-foam specimen

\begin{tabular}{|c|c|c|c|}
\hline $\begin{array}{c}\text { Maximum } \\
\text { diameter ,mm }\end{array}$ & $\begin{array}{c}\text { Minimum } \\
\text { diameter ,mm }\end{array}$ & $\begin{array}{c}\text { Average } \\
\text { diameter ,mm }\end{array}$ & Porosity \% \\
\hline 3.822 & 0.043 & 0.86 & 44.84 \\
\hline
\end{tabular}


This average diameter is taken in consideration in preparation of samples for compression test as illustrated earlier. The average cell size is inversely related both to the average cell wall thickness and to the density and can be influenced by adjusting the impeller speed and other parameters $[3,18]$

\subsection{Effect of Foaming Agent on Foam Density}

As shown in Fig. 5 the relative density $\rho / \rho s$ ( $\rho$ density of Al-foam, $\rho$ s density of solid aluminium) decreases with the increase of $\mathrm{CaCO} 3 \mathrm{wt} \%$, although it seems essentially constant after $2 \%$.

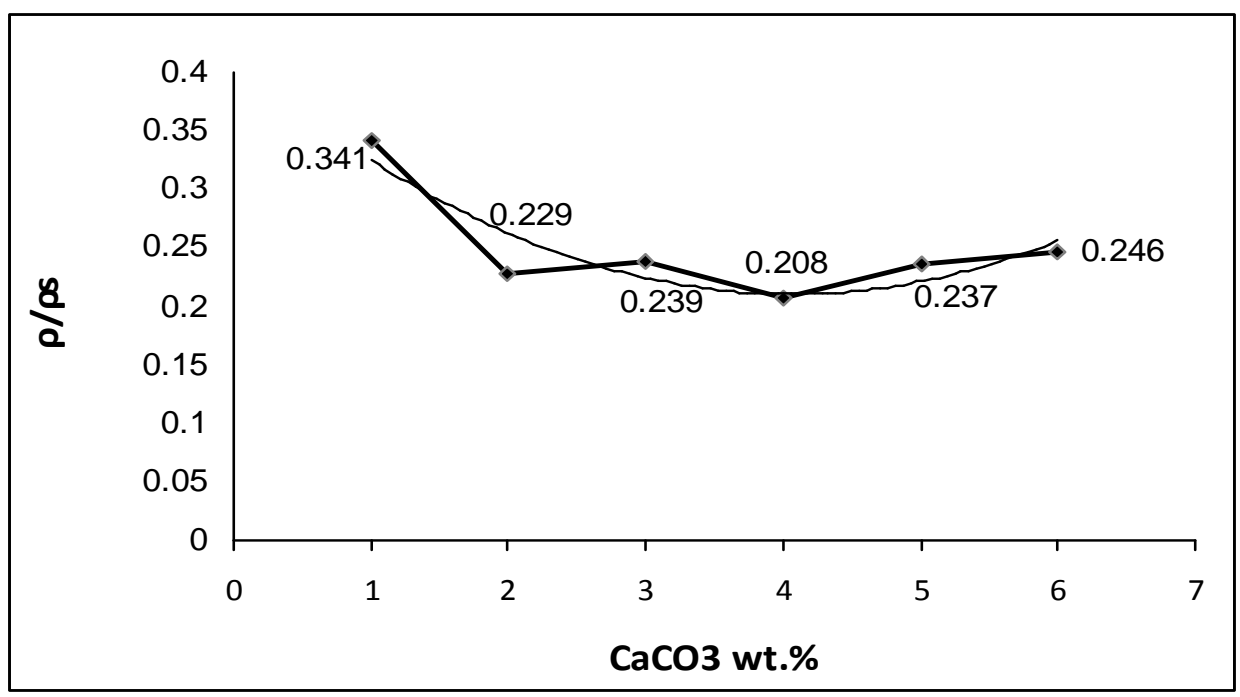

Figure 5: Effect of $\mathrm{CaCO} 3$ addition on foam density

\subsection{Compressive Behavior of Aluminum Foam}

Figure 6 shows the nominal compressive stress-strain curves of Al-foams with different $\mathrm{CaCO} 3$ wt.\%. The stress-strain curves were obtained by dividing the applied load by the cross-sectional area of sample to obtain the stress, and dividing the measured displacement by the length of the specimen to obtain the strain. The stress strain curves can be divided into three stages: (1) an elastic region, where the compressive stress increases with increasing strain almost linearly and the overall elastic deflection of the cell walls takes place (2) a plastic region, where the stress slowly increases with increasing deformation and the initiation and propagation of fracture bands or bucking of the cell walls occurs and (3) a densification region, where the stress rises steeply at high strains and the sufficient collapse of cell walls and packing of broken fragments prevails[17] 


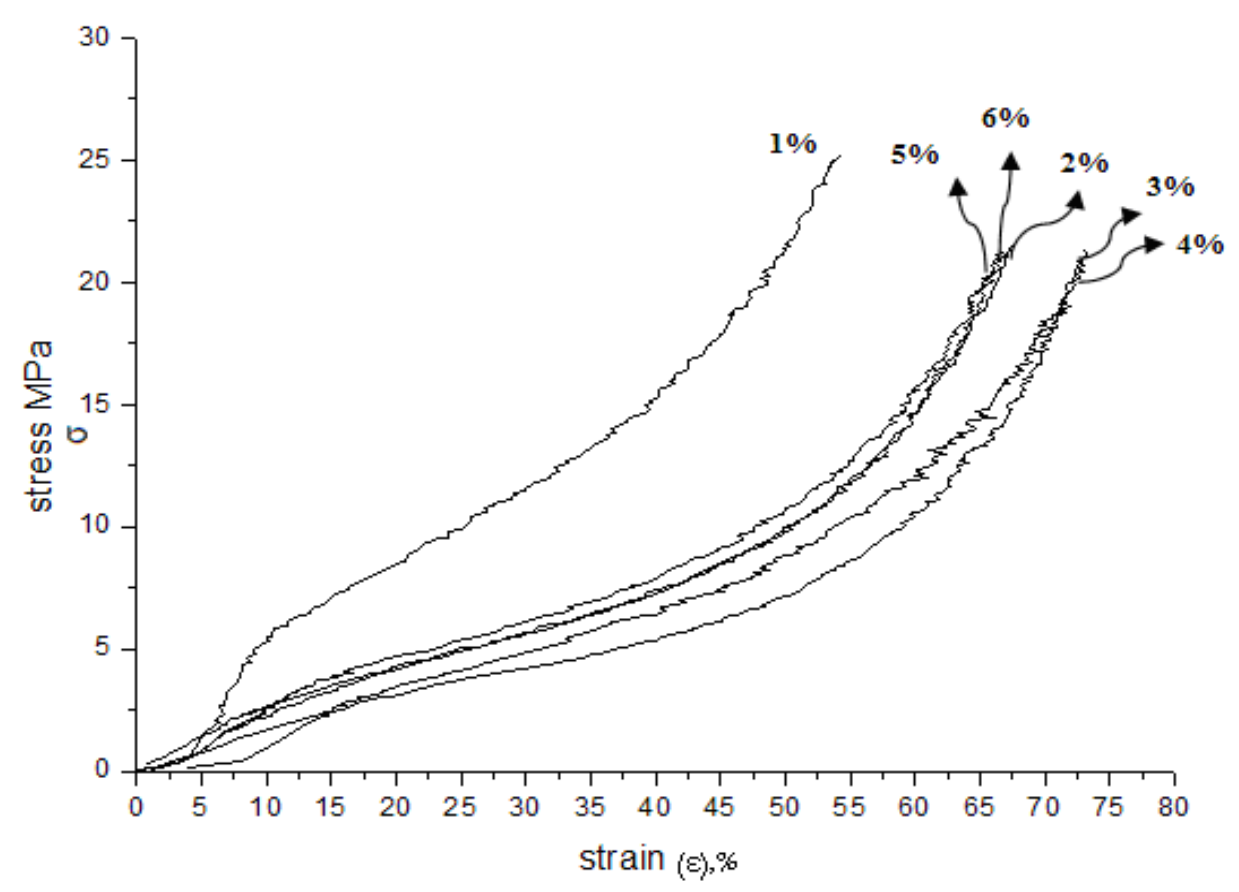

Figure 6: Compressive stress-strain curves of Al-foams with different $\mathrm{CaCO} 3$ wt.\% addition.

\subsection{Energy Absorption Characteristic}

One of the important technological properties to estimate the application of metallic foams is energy absorption capacity. Metallic foams can dissipate energy by the yielding, buckling, fracture of the cell structure, the friction between the cell wall fragments, and sticky flow of the gas trapped in the foams [19]. From compressive stress-strain curve $(\sigma-\varepsilon)$ the compressive properties (plateau stress $\sigma \mathrm{pl}$, densification strain $\varepsilon d$ and energy absorption capacity) of the aluminum foam are determined .The plateau stress $\sigma \mathrm{p} 1$, is taken as the average stress between $5 \%$ and $30 \%$ strain during compression [20-22]. The energy absorption per unit volume, $\mathrm{U}$, is the area under the stress-strain curve up to the onset of densification as shown in Fig.7. The densification strain $\varepsilon d$ is determined where the slope of the stress-strain curve increases steeply (at the nominal compressive stress equals twice the plateau value) [20-22] .

The energy absorption of aluminum foam is related to the area under the compressive stress-strain $(\sigma-\varepsilon)$ curve:

$$
U=\int_{0}^{\varepsilon d} \sigma d \varepsilon
$$

Where $U$ is the energy absorbed per unit initial volume up to the densification strains $\varepsilon d$ [21]. Figures 8(a-c) shows the variation of plateau stress $\sigma p l$, densification strain $\varepsilon d$ and energy absorption capacity $U$ with respect to relative density, respectively. 


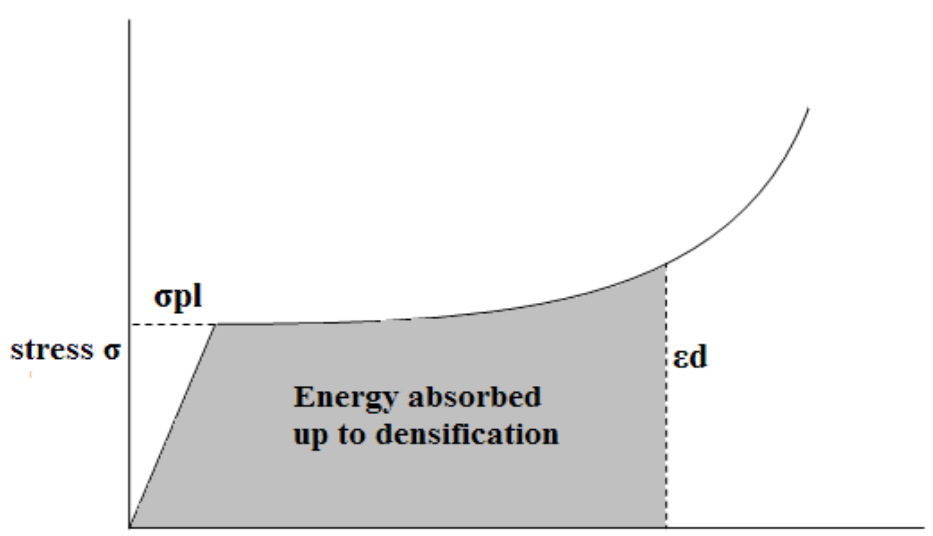

strain $\varepsilon$

Figure 7: Compressive curve for a metal foam - schematic showing properties

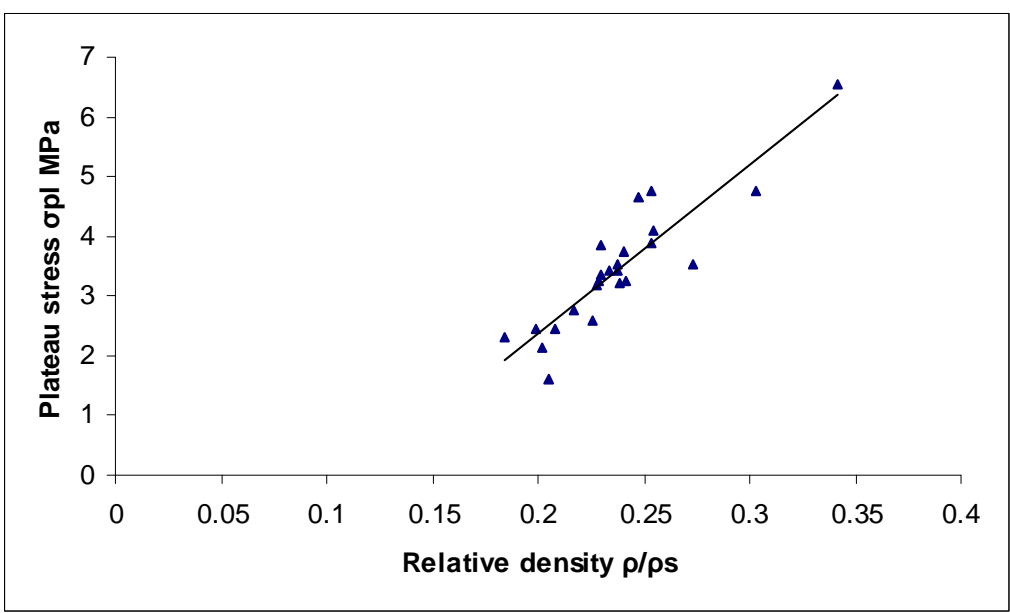

Figure 8-a: Plateau stress $\sigma \mathrm{pl}$ variation with respect to relative density

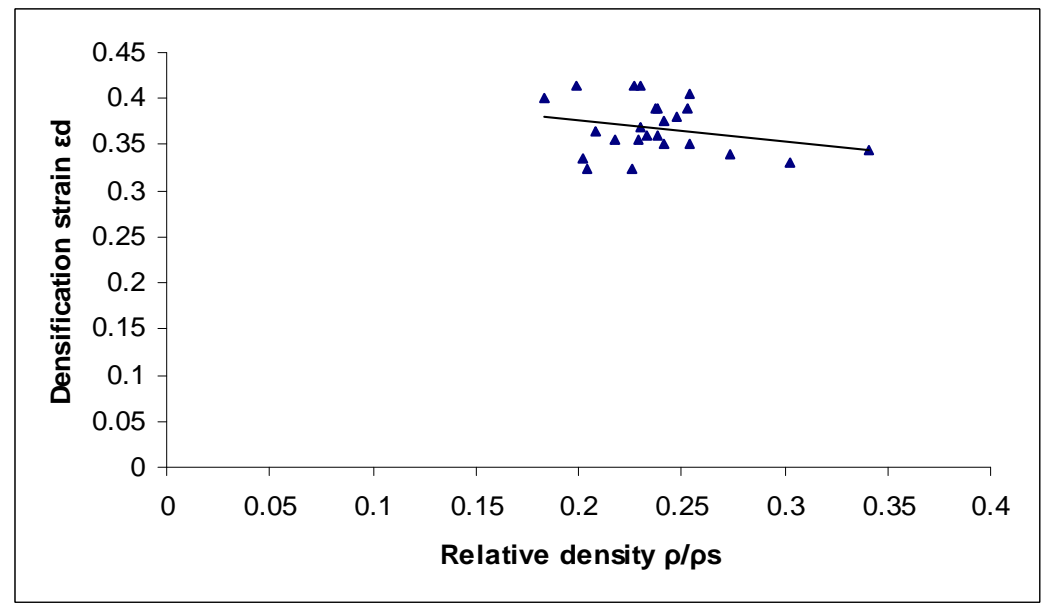

Figure 8-b: Densification strain $\varepsilon d$ variation with respect to relative density 


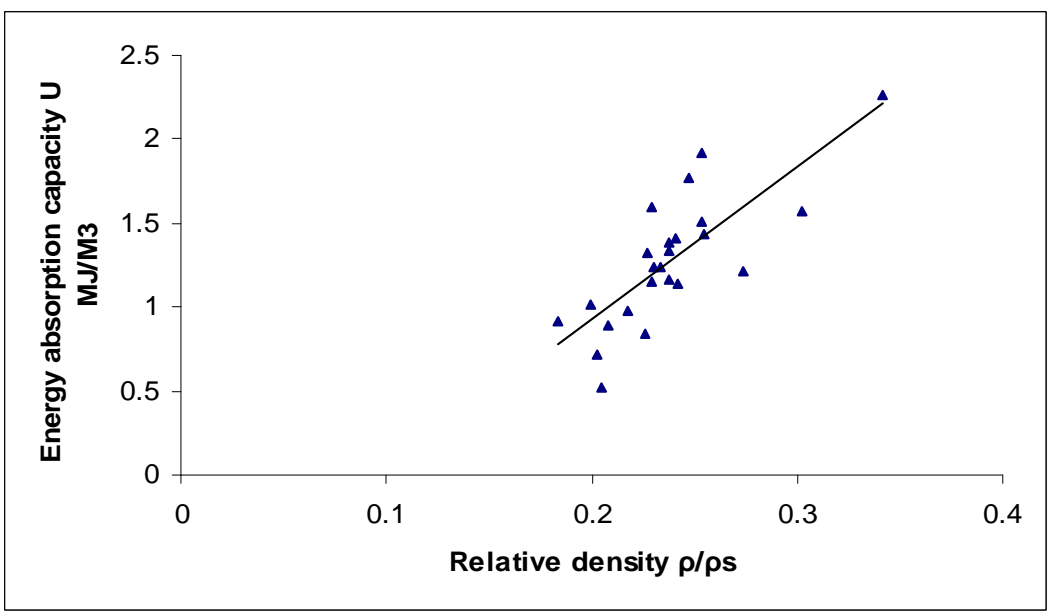

Figure 8-c: Energy absorption capacity U variation with respect to relative density

With increase in relative density plateau stress and energy absorption capacity will increase, but densification strain will decrease.

The energy absorption capacity of metallic foams is mainly due to cells yielding, buckling, fracture, and the friction between cell walls when they contact each other. The foams with higher relative density have higher yield and fracture strength than those with lower density. And they can also provide more friction source during the collapse course because of higher volume fraction of matrix metal in the foams. Therefore, the foams with higher relative density can dissipate more energy than those with lower density during compression. These factors are mainly responsible for the higher energy absorption capacity of higher density foams.[23]

\section{CONCLUSIONS}

Deformation and energy absorption characteristics of Al-foam produced with calcium carbonate as a foaming agent were investigated through uniaxial compression testing. The foam samples were produced with different densities. The following can be concluded:

1- Calcium carbonate can be an efficient foaming agent for producing closed-cell Al-foams with acceptable mechanical properties

2- The lowest density was obtained at about $4 \%$ addition of $\mathrm{CaCO}_{3}$.

3- Energy absorption and plateau stress increase with relative density increase.

\section{REFERENCES}

1- M.F. Ashby, A.G. Evans, N.A. Fleck, L.J. Gibson, J.W. Hutchinson and H.N.G. Wadley: "Metal Foams: A Design Guide", 2000, Butterworth-Heinemann.

2- N. Babcsán1, J. Banhart1, and D. Leitlmeier: "metal foams- manufacture and physics of foaming", Int. Conf. Advanced Metallic Materials, Smolenice, Slovakia, 2003, pp 5-15. 
3- J. Banhart: "Manufacture, characterisation and application of cellular metals and metal foams", Prog. Mater. Sci., 2001, 46, pp 559-362

4- H.P. Degischer: "Handbook of Cellular Metals", WILEY-VCH-Verlag, Foreword, 2002.

5- V. Gergely and T.W. Clyne: "The FORMGRIP Process: Foaming of Reinforced Metals by Gas Release in Precursors", Adv. Eng. Mater., 2000, 2, pp 175-178.

6- A.R. Kennedy and S. Asavavisitchai: "Effects of TiB2 particle addition on the expansion, structure and mechanical properties of PM Al foams", Scripta Mater., 2004, 50, pp 115-119.

7- S.W. Ip, Y. Wang and J.M. Toguri: "Aluminum foam stabilization by solid particles", Can. Met. Q., 1999,38, pp 81-92.

8- V. Gergely, L. Jones and T.W. Clyne: " The effect of capillarity-driven melt flow and size of particles in cell faces on metal foam structure evolution ", Trans. JWRI., 2001,30, pp 371-376.

9- O. Parkash, H. Sang and J.D. Embury: "structure and properties Al-SiC foam", Mater. Sci. Eng. A , 1995, 199, pp 195-203.

10- J.A. Liu, S.R. Yu, Z.Q. Hu, Y.H. Liu and X.Y. Zhu: "Deformation and energy absorption characteristic of Al2O3f/Zn-Al composite foams during compression", Journal of Alloys and Compounds 2010, 506, pp 620-625

11- Jiaan Liu a, Sirong Yu a, Xianyong Zhu b, Ming Wei a, Song Li c, Yanru Luo b and Yaohui Liu: " Effect of Al2O3 short fiber on the compressive properties of Zn-22Al foams", Materials Letters , 2008 ,62, pp 3636-3638

12- V. Gergely, D.C. Curran and T.W. Clyne: " The FOAMCARP process: foaming of aluminium MMCs by the chalk-aluminium reaction in precursors", Composites Science and Technology, 2003, 63, pp 2301-2310.

13- Marco Haesche, Dirk Lehmhus1, JÄorg Weise, Manfred Wichmann and Irene Cristina Magnabosco Mocellin: ", Carbonates as Foaming Agent in Chip-based Aluminium Foam Precursor", J. Mater. Sci. Technol., 2010, 26(9), pp 845-850.

14- Nawal E. Abdullatef and Adel Mohammad: "Preparation of Al-12Si Foam Using Liquid Technique", Eng. \& Tech. Journal, 2009, 27(12), pp 2479-2493 ol.27, No.12,2009 Eng. \& Tech. Journal, Vol.27, No.12,2009

15- Mohamed Shehata Aly: "Behavior of closed cell aluminium foams upon compressive testing at elevated temperatures: Experimental results", Materials Letters, 2007, 61, pp 3138-3141

16- S.W. Youn and C.G. Kang: "Evaluation of Mechanical Properties of Porous 6061 Alloys Fabricated by the Powder Compression and Induction Heating Process", met. \& mat. Trans. A, 2004, 35, pp 2419-2426

17- D. P. Papadopoulos, H. Omar, F. Stergioudi, S. A. Tsipas, H. Lefakis and N. Michailidis: "A novel method for producing Al-foams and evaluation of their compression behavior", J Porous Mater, 2010, 17(6), pp 773-777

18- L.D Kenny: "Mechanical Properties of Particle Stabilized Aluminum Foam",Materials science forum, 1996, 217-222, pp 1883-1890.

19- L.J. Gibson and M.F. Ashby: "Cellular Solids: Structure and Properties", Second ed., Cambridge University Press, Oxford, 1997.

20- 20 - R. Edwin Raj and B.S.S. Daniel: "Prediction of compressive properties of closed-cell aluminum foam using artificial neural network", Computational Materials Science, 2008, 43, pp 767-773 
21- O.B. Olurin, N.A. Fleck and M.F. Ashby: "Deformation and fracture of aluminium foams", Mat. Science and Eng. A, 2000, 291, pp 136-146

22- R. Edwin Raj, Venkitanarayanan Parameswaran and B.S.S. Daniel: "Comparison of quasi-static and dynamic compression behavior of closed-cell aluminum foam", Mat. Science and Eng. A, 2009, 526, pp 11-15.

23- Sirong Yu, Jiaan Liu, Ming Wei, Yanru Luo, Xianyong Zhu and Yaohui Liu: " Compressive property and energy absorption characteristic of open-cell ZA22 foams", Materials and Design, 2009, 30, pp 87-90.

\section{أنتاج الالومنيوم الرغوى وتأثير أستخام كريونات الكالسيوم كعامل ترغية}

يعتبر الالومنيوم الرغوى من المواد الهندسية الجديدة المهمة لما لها من تطبيقات كثيرة فى المنشأت خفيفة الوزن وأمتصاص الصدمات وغيرها من التطبيقات الكثيرة. وقد تم أنتاج الالومنيوم الرغوى بكثنافات

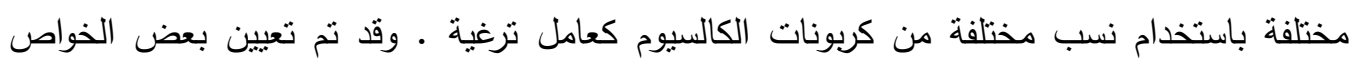

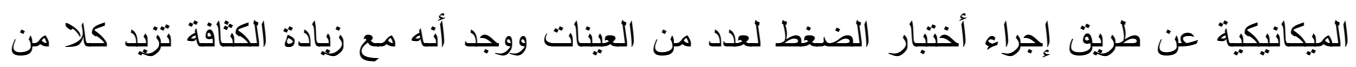
القدرة على أمنصاص الطاقة (U) و الاجهاد اللازم للإنهيار (opl). 